\title{
Authority by Representation - A New Form of Authority?
}

RD Sharrock*

\section{P.E.R}

Pioneer in peer-reviewed, open access online law publications.

Author

RD Sharrock

Affiliation

University of KwaZulu Natal, South Africa

Email: sharrock@ukzn.ac.za

Date published

7 December 2016

Editor Dr A Gildenhuys

How to cite this article

Sharrock RD "Authority by

Representation - A New Form of Authority?" PER / PELJ 2016(19) DOI

http://dx.doi.org/10.17159/1727-

3781/2016/v19i0a1240

\section{Copyright}

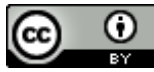

DOI

http://dx.doi.org/10.17159/1727-

3781/2016/v19i0a1240

\begin{abstract}
The majority decision in Makate $v$ Vodacom (Pty) Ltd [2016] ZACC 13 recognises a new form of actual authority - authority by representation. However, the decision is based on a misinterpretation of English law and is inconsistent with an extensive body of South African case law and the view held by several South African text-book writers. It remains to be seen whether the decision will be regarded as binding authority. If it is accepted as binding, the principle of agency by representation which it establishes will need to be clarified and developed in certain respects to ensure that it does not operate unfairly.
\end{abstract}

\section{Keywords}

Authority; estoppel; law of agency; ostensible; stare decisis. 


\section{Introduction}

The authority to conclude a contract on behalf of another may originate from a variety of sources, including authorisation by the principal party, employment in a particular capacity, and delegation. The expressions "apparent authority" and "ostensible authority" have hitherto been used in this context to describe contractual liability arising by reason of the doctrine of estoppel: the situation in which a would-be agent contracts without authority and the principal party is unable to avoid contractual liability because he or she is precluded by the doctrine of estoppel from proving facts to refute the allegation that the "agent" had authority. In Makate $v$ Vodacom (Pty) Ltd, ${ }^{1}$ ("Makate") the majority of the Constitutional Court adopted a different approach. It held that the expressions "apparent authority" and "ostensible authority" refer to a particular type of actual authority - one arising from a representation of authority by the principal party - and, accordingly, it is incorrect to regard them as convenient or shorthand means of describing liability based on estoppel. Counsel in Makate were not asked to address legal argument on whether ostensible authority should be recognised as a form of actual authority and the majority judges, in reaching their decision, misinterpreted or ignored a large body of judicial precedent and academic writing. Ironically, it appears that there was no need for them to adopt the course that they did. Wallis AJ, in his minority judgment, had no difficulty in reaching the same outcome as the majority by applying trite principles of representation.

\section{The facts}

The applicant (Makate), employed by the respondent (Vodacom) as a trainee accountant, came up with an idea for enabling a cellphone user who has no airtime to send a request to another cellphone user with airtime to call him or her. Realising that his idea had commercial potential, Makate incorporated it into a written memorandum and sent the memorandum to his immediate line manager (Muchenje), with copies to the Chief Executive Officer (CEO) of the Vodacom Group (Knott-Craig) and other senior executives. Makate explained to Muchenje that he wished to be remunerated for the idea and, if Vodacom was not interested, he would take the idea to a competitor. Muchenje undertook to discuss the idea with the Director of Product Development and Management

Robert Douglas Sharrock, B Com LLB (Natal). Professor at the UKZN School of Law, Pietermaritzburg Campus, South Africa. Email: sharrock@ukzn.ac.za.

[2016] ZACC 13. 
(Geissler). When the latter responded favourably, Makate sent the written memorandum to him. After the Department of Product Development and Management had discovered how to make Makate's idea technically feasible, Makate and Geissler met and agreed that if Vodacom launched a product in accordance with Makate's idea and the product was a commercial success, Makate would be paid a share of the revenue generated. Makate indicated that he wanted $15 \%$ of this revenue, but the parties agreed to defer to a later date their negotiations on the amount that he was to receive. They also agreed that if they could not reach consensus on the amount to be paid, the question of remuneration would be referred to Vodacom's CEO for determination.

Based on Makate's idea, Vodacom developed a new service called "Please Call Me". This enabled a prepaid cellphone user with no airtime to send a text message to another cellphone user, asking the latter to call him or her. In an email addressed to staff and in an internal newsletter, Vodacom acknowledged that Makate was the inventor of the idea behind the product and praised him for conceiving of the idea, when his job was not related to product development. The product was immediately popular with customers and, in due course, generated billions of rands in revenue for Vodacom. Despite this, Vodacom did not negotiate with Makate on the amount of compensation to be paid to him for his idea. Instead, KnottCraig and Geissler dishonestly credited Knott-Craig with the idea.

\section{Legal proceedings}

About four years after the launch of the "Please Call Me" product, Makate (who, in the interim, had left the employ of Vodacom) instituted action against Vodacom for an order directing it to enter into bona fide negotiations with him to reach agreement on a reasonable remuneration for his idea. Makate based his claim on a contract between himself and Vodacom. In his particulars of claim he alleged that Geissler had actual authority to conclude the contract on behalf of Vodacom; alternatively, ostensible authority to do so. By the close of his case, Makate had abandoned the allegation of actual authority and relied solely on ostensible authority.

The trial court held that Makate had failed to establish the requirements of estoppel and that Makate's claim had in any event prescribed.

After both the trial court and the Supreme Court of Appeal refused leave to appeal, Makate applied to the Constitutional Court, which granted leave. 
This court considered that it had jurisdiction to entertain the matter because it raised a constitutional issue (the interpretation of the Prescription Act 68 of 1969 in the light of section 39(2) of the Constitution of the Republic of South Africa, 1996) and it was in the interests of justice to grant the application. ${ }^{2}$

The Constitutional Court upheld the appeal. Jafta J, who delivered the majority judgment, ${ }^{3}$ declared that Vodacom was bound by the contract concluded by Makate and Geissler and ordered Vodacom to commence negotiations in good faith with Makate for determining a reasonable compensation to be paid to him. Failing agreement, the matter was to be submitted to Vodacom's CEO for determination of the amount within a reasonable time. ${ }^{4}$

Wallis AJ delivered a minority concurring judgment ${ }^{5}$ in which he agreed with the order made by the majority. ${ }^{6}$ However, he arrived at this outcome via a different line of reasoning.

\section{$4 \quad$ The majority judgment}

Jafta $\mathrm{J}$ identified the two main issues to be decided as whether the ostensible authority relied on by Makate had been established and whether Makate's claim had prescribed. ${ }^{7}$ He decided both issues in favour of Makate. The main points in his reasoning on ostensible authority were the following.

The trial court's conclusion was that Makate could not rely on estoppel because he had failed to plead or prove facts giving rise to an estoppel. ${ }^{8}$ This conclusion was based on flawed reasoning because it proceeded on the basis that Makate had raised the issue of estoppel. The trial court had "conflated ostensible authority with estoppel." This was incorrect: ostensible authority and estoppel, although at times treated as synonymous by our courts, are not the same. ${ }^{9}$ Actual authority and ostensible or apparent authority are "opposite sides of the same coin". ${ }^{10} \mathrm{~A}$

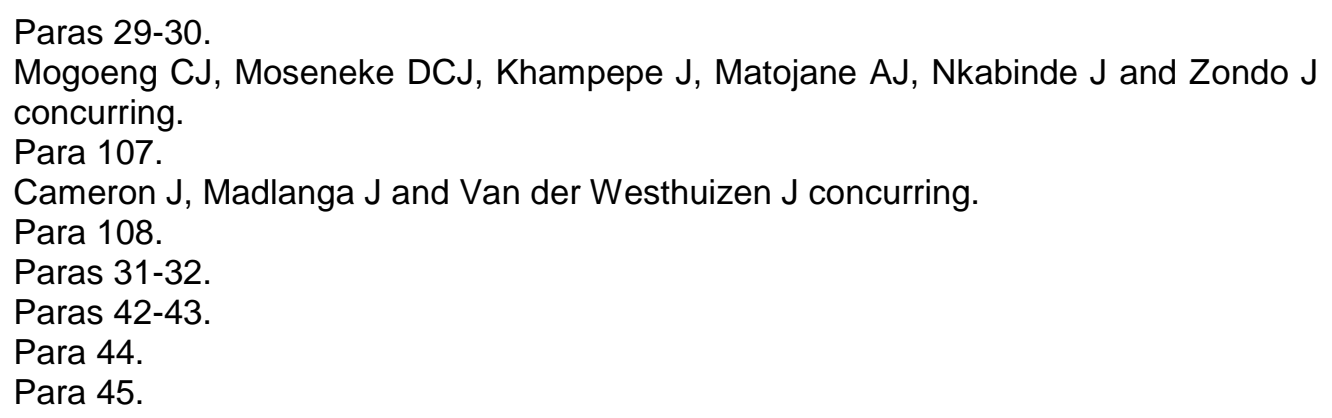


misrepresentation that gives rise to estoppel may also lead to an appearance that the agent has the power to act on behalf of the principal. This is known as ostensible or apparent authority in our law. While this kind of authority may not have been conferred by the principal, it is still taken to be the authority of the agent, as it appears to others. It is distinguishable from estoppel, which is not authority at all. Estoppel and apparent authority have different elements, barring one element that is common to both. This is the representation, which may take the form of words or conduct. ${ }^{11}$

\section{In Hely-Hutchinson v Brayhead Ltd ${ }^{12}$ ("Hely-Hutchinson"), Lord Denning MR said:}

(A)ctual authority may be express or implied. It is express when it is given by express words, such as when a board of directors pass a resolution which authorises two of their number to sign cheques. It is implied when it is inferred from the conduct of the parties and the circumstances of the case, such as when the board of directors appoint one of their number to be managing director. They thereby impliedly authorise him to do all such things as fall within the usual scope of that office. Actual authority, express or implied, is binding as between the company and the agent, and also as between the company and others, whether they are within the company or outside it.

Ostensible or apparent authority is the authority of an agent as it appears to others. It often coincides with actual authority. Thus, when the board appoint one of their number to be managing director, they invest him not only with implied authority, but also with ostensible authority to do all such things as fall within the usual scope of that office. Other people who see him acting as managing director are entitled to assume that he has the usual authority of a managing director. But sometimes ostensible authority exceeds actual authority. For instance, when the board appoint the managing director, they may expressly limit his authority by saying he is not to order goods worth more than $£ 500$ without the sanction of the board. In that case his actual authority is subject to the $£ 500$ limitation, but his ostensible authority includes all the usual authority of a managing director. The company is bound by his ostensible authority in his dealings with those who do not know of the limitation. He may himself do the "holding-out". Thus if he orders goods worth $£ 1,000$ and signs himself "Managing Director for and on behalf of the company", the company is bound to the other party who does not know of the $£ 500$ limitation. ${ }^{13}$

A "closer examination" of this passage reveals that authority is established if a principal by words or conduct creates an appearance that another party has the power to act on his or her behalf. Nothing more is required. The means by which the appearance of authority is represented need not

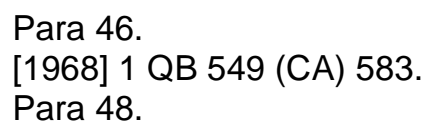


be directed at any person. In other words the principal need not make the representation of authority to the person claiming that the agent had apparent authority. ${ }^{14}$

The fact that Lord Denning MR stated that "[o]stensible or apparent authority is the authority of an agent as it appears to others" is "significant", because this underscores the distinction between ostensible authority and estoppel. ${ }^{15}$

Our courts have "sometimes conflated apparent authority with estoppel", which has led to their incorrectly "attributing the elements of estoppel to apparent authority". A case in point is NBS Bank Ltd v Cape Produce Company Pty Ltd" ("NBS Bank"). In that case, after quoting the above passage from the judgment of Lord Denning MR in Hely-Hutchinson, Schutz JA said: 17

As Denning MR points out, ostensible authority flows from the appearances of authority created by the principal. Actual authority may be important, as it is in this case, in sketching the framework of the image presented, but the overall impression received by the viewer from the principal may be much more detailed. Our law has borrowed an expression, estoppel, to describe a situation where a representor may be held accountable when he has created an impression in another's mind, even though he may not have intended to do so and even though the impression is in fact wrong. Where a principal is held liable because of the ostensible authority of an agent, agency by estoppel is said to arise. But the law stresses that the appearance, the representation, must have been created by the principal himself. The fact that another holds himself out as his agent cannot, of itself, impose liability on him.... And it is not enough that an impression was in fact created as a result of the representation. It is also necessary that the representee should have acted reasonably in forming that impression.

Schutz JA proceeded to state the elements of estoppel as elements of apparent authority. In doing this he "conflated ostensible authority with estoppel" and overlooked the observation in Hely-Hutchinson CA that apparent authority is the agent's authority as it appears to others. ${ }^{18}$ Nothing in Hely-Hutchinson suggests that apparent authority may be equated to estoppel. The converse appears to be true. ${ }^{19}$

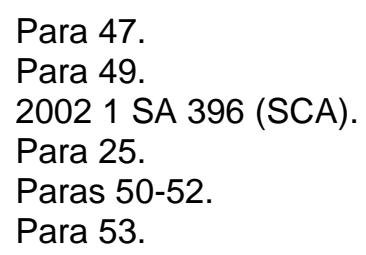


The Supreme Court of Appeal continued the conflation of estoppel and apparent authority in South African Broadcasting Corporation v Coop, ${ }^{20}$ where it declared:

The plaintiffs in a replication relied on estoppel, otherwise described as ostensible authority. A person who has not authorised another to conclude a juristic act on his or her behalf may in appropriate circumstances be estopped from denying that he or she had authorised the other so to act. The effect of a successful reliance on estoppel is that the person who has been estopped is liable as though he or she had authorised the other to act. 21

Apart from NBS Bank and subsequent decisions that have followed it, ${ }^{22}$ there is not a single case referred to in our law that holds that apparent authority is estoppel. ${ }^{23}$

In considering whether Makate had established that Geissler had apparent authority when they concluded their agreement, the trial Court incorrectly applied the test for determining whether estoppel was established instead of whether apparent authority was proved. Consequently its conclusion was "mistaken". ${ }^{24}$

The question had to be assessed against the facts which emerged from the evidence and were accepted by the trial court. Vodacom had a system by which Makate's idea could be developed as a new service for the public. Crucial to the operation of this system was the authority conferred on Geissler, a board member of Vodacom, who had the portfolio of Director of Product Development and Management. He was empowered to consider new products and subject them to technical and commercial viability tests before accepting them as part of Vodacom's business offerings. He was Vodacom's front man in its dealings with new products and the successful introduction of a new product depended solely on him. ${ }^{25} \mathrm{He}$ concluded an agreement with Makate to use his idea in developing a new product for Vodacom and to defer negotiations on remuneration. ${ }^{26}$

20062 SA 217 (SCA) para 62.

Para 54.

Northern Metropolitan Local Council v Company Unique Finance (Pty) Ltd 20125

SA 323 (SCA); South African Broadcasting Corporation v Coop 20062 SA 217

(SCA); Glofinco v Absa Bank 20026 SA 470 (SCA).

23 Para 70.

24 Para 60.

25 Para 62.

26 Para 63. 
Vodacom's contention was that although it had conferred enormous power on Geissler, he had not been given authority to bind it. However, this was not the issue. The question was whether, as it appeared to others, Geissler had authority to bind Vodacom. ${ }^{27}$ Jafta J elaborated.

This question must be considered with the view to doing justice to all concerned. The concept of apparent authority as it appears from the statement by Lord Denning, was introduced into law for purposes of achieving justice in circumstances where a principal had created an impression that its agent has authority to act on its behalf. If this appears to be the position to others and an agreement that accords with that appearance is concluded with the agent, then justice demands that the principal must be held liable in terms of the agreement. It cannot be gainsaid that on present facts, there is a yearning for justice and equity. ${ }^{28}$

When account was taken of Geissler's position in Vodacom, the enormous power he wielded in respect of new products, the organisational structure within which he exercised this power and the process which had to be followed before a new product could be introduced at Vodacom, there was only one appearance that emerged. It was that Geissler had authority to negotiate all issues relating to the introduction of new products at Vodacom, including the amount to be paid for a new product once it had been tested, approved and acquired by Vodacom. Owing to his technical skills, he was best placed to determine the worth of a new product. ${ }^{29}$

Makate, accordingly, had established that Geissler had apparent authority to bind Vodacom. ${ }^{30}$

\section{$5 \quad$ The minority judgment}

The minority judgment delivered by Wallis AJ serves a twofold purpose: it identifies the obvious weaknesses in the majority judgment and it demonstrates how the court should have decided the matter, applying ordinary principles of representation.

Wallis AJ agreed with the main judgment on the following points: that the key issue was whether Vodacom had represented that Geissler had authority to conclude the contract with Makate; that Vodacom had, in fact, made this representation; and that Geissler had ostensible authority to conclude the contract. ${ }^{31}$ Where Wallis AJ disagreed with the main

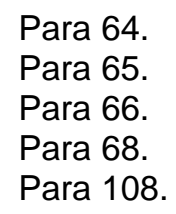


judgment was in regard to "the juristic nature of ostensible authority where there is no actual authority". The acting judge pointed out that it is "settled law" that ostensible authority is "a form or instance of estoppel" and this is why judgments and textbooks commonly refer to it as "agency by estoppel". His disagreement with the majority view on this issue did not affect the outcome of the case but the majority view had "the potential to cause unnecessary confusion in a settled area of the law, which is undesirable." 32 Wallis AJ listed the considerations which had motivated him to deliver his minority judgment.

\begin{abstract}
First, the issue was not debated before us and we were not asked to alter the settled legal position. Second, my colleague's approach is based on his understanding of the English law. That understanding, based as it is on a single sentence in a judgment of Lord Denning in the Court of Appeal in Hely-Hutchinson $v$ Brayhead Ltd and Another [1968] 1 QB 549 (CA), is inconsistent with the authoritative judgments of English courts. Third, his approach is inconsistent with the judgments of our courts since the early twentieth century as well as the views of our textbook writers. Fourth, he advances no reason of principle for adopting this approach and does not locate it in any constitutional imperative. Fifth, the enquiry arose only because of the erroneous approach of the trial Court to the proper pleading of apparent or ostensible authority. ${ }^{33}$
\end{abstract}

Wallis AJ commenced his discussion by pointing out that estoppel is a wide-ranging and equitable concept that finds application in a number of different settings, including motor dealer cases, share dealing transactions, and vindicatory actions. The law reports contain countless examples of the doctrine's being applied. The acting judge was convinced, on both principle and authority, that "ostensible authority is merely one more instance of estoppel"; one that crops up frequently in practice when there is no express or implied authority. In some cases, ostensible authority coincides with implied actual authority, and in those cases actual and ostensible authority are (to borrow Jafta J's metaphor) "two sides of the same coin". However, in the case before the court it was accepted that there was no authority at all, express or implied, and so this took the case "into the realm of estoppel". 34

Wallis AJ's criticisms of the majority judgment were, in summary, the following.

In the majority judgment, Jafta $\mathrm{J}$ rejected the trial court's view that ostensible authority is a form of estoppel and held that, although

\footnotetext{
Para 109

Para 109.

Para 110.
} 
sometimes ostensible authority and estoppel have been treated as synonymous by our courts, they are not the same. In other words, ostensible authority is a form of actual authority. ${ }^{35}$ Jafta based this view on a single sentence by Lord Denning in Hely-Hutchinson 583, that "[o]stensible or apparent authority is the authority of an agent as it appears to others." Jafta $\mathrm{J}$ considered that this statement was incorporated into our law when Schutz JA cited it with approval in NBS Bank, even though, in so doing, Schutz JA mistakenly conflated apparent authority and estoppel. ${ }^{36}$

Jafta was wrong in two respects. The first error was the suggestion that English law differentiates between apparent authority and estoppel. In English law, apparent or ostensible authority clearly falls under the rubric of estoppel and is treated as an instance of estoppel by representation. This is manifest from the leading cases of Freeman \& Lockyer (a firm) $v$ Buckhorst Park Properties (Mangal) ${ }^{37}$ and Armagas Ltd $v$ Mundogas SA (The Ocean Frost). ${ }^{38}$ The latter provides the definitive statement of English law on the point and, being a judgment of the House of Lords, is binding on all other courts. In a key passage, ${ }^{39}$ Lord Keith stated unequivocally that ostensible authority is nothing more than estoppel. ${ }^{40}$

The second flaw in Jafta J's reasoning is the suggestion that Schutz JA, in treating apparent or ostensible authority as a form or instance of estoppel, was departing from the principles applied in our law before NBS Bank. Jafta $\mathrm{J}$ expressed the view ${ }^{41}$ that, prior to NBS Bank and the decisions that followed it, there was not a single case in our law which held that apparent authority is estoppel. This is incorrect. ${ }^{42}$ Our courts have, from early times, consistently taken the view that apparent or ostensible authority is merely an instance of estoppel, as is evident from a long line of cases decided before NBS Bank. ${ }^{43}$ Textbook writers ${ }^{44}$ have also taken this view. ${ }^{45}$

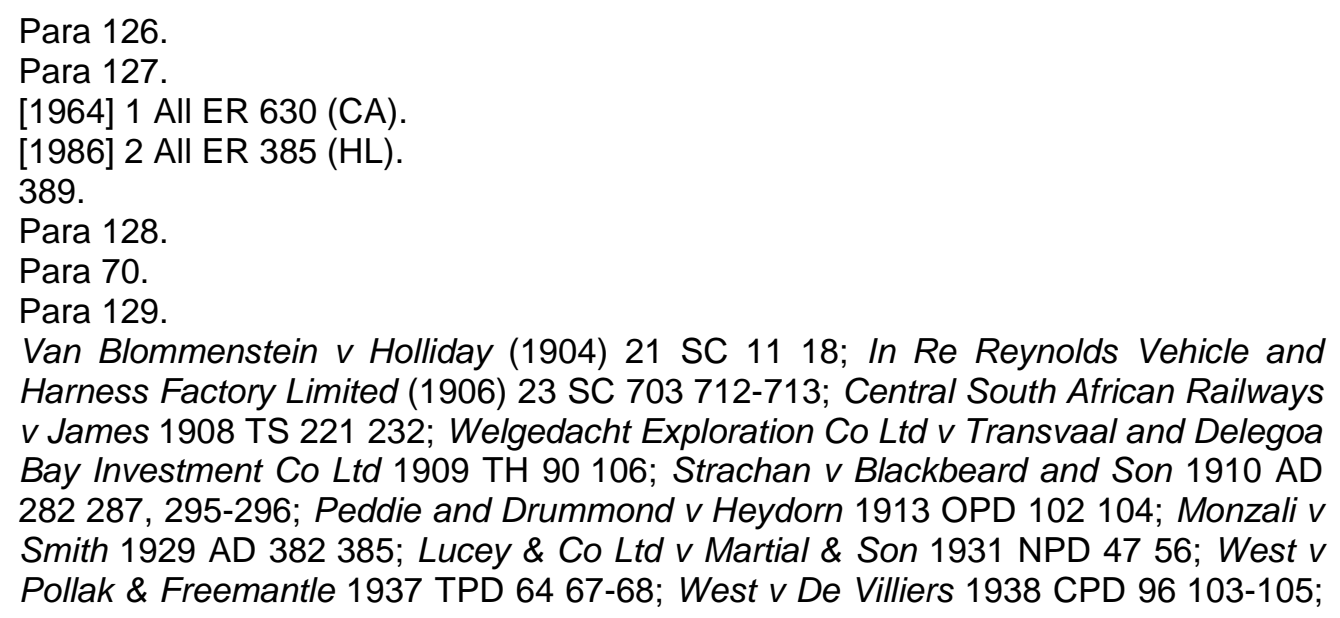
Harness Factory Limited (1906) 23 SC 703 712-713; Central South African Railways $v$ James 1908 TS 221 232; Welgedacht Exploration Co Ltd v Transvaal and Delegoa Bay Investment Co Ltd 1909 TH 90 106; Strachan v Blackbeard and Son 1910 AD 282 287, 295-296; Peddie and Drummond v Heydorn 1913 OPD 102 104; Monzali v Smith 1929 AD 382 385; Lucey \& Co Ltd v Martial \& Son 1931 NPD 47 56; West $v$ Pollak \& Freemantle 1937 TPD 64 67-68; West v De Villiers 1938 CPD 96 103-105; 
NBS Bank was the first of a series of cases in which the Supreme Court of Appeal dealt with these issues. It concerned the authority of a branch manager of a bank to take investments from members of the public. Schutz JA cited the passage from the judgment of Lord Denning MR in Hely Hutchinson (quoted above) and placed the question of ostensible authority squarely within the framework of estoppel. ${ }^{46}$ The Supreme Court of Appeal, in a series of subsequent cases, ${ }^{47}$ had reaffirmed Schutz JA's approach. 48

Wallis AJ concluded:

[T]he [preceding] analysis ... shows that in English law ostensible authority is an estoppel by representation and that the earlier decisions of our courts that say that ostensible or apparent authority is a form of estoppel are correct. That is also the view of the academic commentators ... This characterisation was not and is not challenged on the basis that it is inconsistent with the spirit, purport and objects of the Bill of Rights. It should in my opinion be applied in this case. Therefore, once Mr Makate accepted that $\mathrm{Mr}$ Geissler did not have actual authority, whether express or implied, to conclude a contract with him on behalf of Vodacom, he had to show that Vodacom made a representation to him that Mr Geissler had the requisite authority and that he reasonably acted upon it. ${ }^{49}$

In response to Wallis AJ's judgment, Jafta $\mathrm{J}$ had raised the consideration that his (Jafta J's) approach regarding apparent authority and estoppel was analogous to the approach adopted in relation to the principle of "apparent agreement" (quasi-mutual assent) and the objective theory of contract. He explained.

Insurance Trust \& Investments v Mudaliar 1943 NPD 45 58, 61-63; Clifford Harris (Rhodesia) Ltd v Todd 19553 SA 302 (SR) 303; Tuckers Land and Development Corporation (Pty) Ltd v Perpellief 19782 SA 11 (T) 14, 18-19; Inter-Continental Finance \& Leasing Corp (Pty) Ltd v Stands 56 and 57 Industria Ltd 19793 SA 740 (W) 748; Southern Life Association Ltd v Beyleveld 19891 SA 496 (A) 503; African Life Assurance Co Ltd v NBS Bank Ltd 20011 SA 432 (W) 451; Glofinco v ABSA Bank Ltd (t/a United Bank) 20012 SA 1048 (W) 1064.

$44 \quad$ The judge referred to Kerr Agency 112-148; De Villiers and Macintosh Agency 119; Joubert Verteenwoordigingsreg 109-115; De Wet and Van Wyk Kontraktereg 101; Wille Mercantile Law 466-468; Wille Principles 991. Also see Sonnekus Estoppel 23, 93-99, 124-125.

45 Paras $140-143$ and $145-149$.

46 Paras 150-151.

47 Glofinco v Absa Bank 20026 SA 470 (SCA) para 13; South African Broadcasting Corporation v Coop 20062 SA 217 (SCA) paras 64-66; MEC for Economic Affairs, Environment and Tourism v Kruizenga 20104 SA 122 (SCA) paras 15-16; Northern Metropolitan Local Council v Company Unique Finance (Pty) Ltd 20125 SA 323 (SCA) paras 28-29.

48 Para 152.

49 Para 154. 
[l]f a person conducts herself in a manner that would reasonably cause another to believe that she was assenting to contractual terms proposed by the latter, and acting on that belief the latter enters into a contract with her, she would be bound as if she had intended to agree, even though that may not have been her intention ... In our law this kind of contract is known as the apparent agreement because it does not have consensus as its foundation. What is clear though is that the objective theory of contract is not construed to mean estoppel, even though they both apply and arise from the same facts ... I can think of no reason in principle or logic which warrants a different approach in the case of apparent authority and estoppel. Both apparent contract and apparent authority derive their existence from the conduct of the party to be held liable. Both form part of our law of contract. They come into being from what reasonably appears to be the position. Therefore, if a distinction is drawn between estoppel and the objective theory of contract in the case of the apparent agreement, the same should be the position in respect of apparent authority and estoppel in contracts of agency. ${ }^{50}$

\section{Wallis AJ was not convinced by this reasoning.}

[Jafta J's] suggestion [is] that my approach is contrary to principle and the approach our law takes to the doctrine of quasi-mutual assent. The example is given of a person who is held liable on a contract because they reasonably caused the other party to believe that they were agreeing to conclude a contract with them. That has on several occasions been treated as estoppe ${ }^{51}$ but in [Saambou-Nasionale Bouvereniging $v$ Friedman ${ }^{52}$ ], Jansen JA said that it would lead to greater clarity to distinguish quasimutual assent and the reliance theory of contract from estoppel. The problem he was addressing was whether our law of contract is wholly subjective and based on the existence of consensus ad idem (subjective agreement, which he referred to as the "wilsteorie" of contract ${ }^{53}$ ) or whether it includes objective elements, which he described as the reliance theory. This bears no resemblance to the issue that arises in relation to the authority to conclude a contract. In the former case the issue is a single one of whether there is any contract at all. In the latter there is a contract, but one of the parties claims that the person purporting to represent it lacked authority to contract. This involves two separate enquiries, namely, whether there was express or implied authority and, if not, whether there was ostensible authority. Whatever reasons there may be for distinguishing between quasi-mutual assent and the objective approach to whether a contract was concluded, they have no bearing on the issue of ostensible authority. The two situations are not in my view comparable. ${ }^{54}$

In relation to the case before him, Wallis AJ could see no difficulty of principle or practicality in treating ostensible authority as estoppel. There had to be a representation of authority by Vodacom and Makate should

50 Paras 72-74.

51 Van Ryn Wine and Spirit Co v Chandos Bar 1928 TPD 417 424; Peri-Urban Areas Health Board v Breet 19583 SA 783 (T) 790; Benjamin v Gurewitz 19731 SA 418 (A) 425 .

$52 \quad 19793$ SA 978 (A) 1002.

53993.

54 Para 157. 
have relied upon that representation. ${ }^{55}$ Furthermore, the representation had to have been one that Vodacom should reasonably have thought would be relied on, and Makate's reliance on it had to have been reasonable. These requirements did not pose any difficulty on the facts. Lastly there was the issue of prejudice, which was obvious. For Makate to permit Vodacom to develop his idea in a false belief that he would be able to negotiate compensation for it plainly redounded to his prejudice. ${ }^{56}$

Applying the above requirements, Wallis AJ concluded that Vodacom was estopped from denying that Geissler had authority to make the contract on its behalf. ${ }^{57}$ His reasoning was, briefly, as follows.

Makate had acted upon the belief that Geissler had authority to conclude a contract with him. In view of Geissler's position in the company, that belief was reasonable. ${ }^{58}$

The crucial issue was whether Vodacom had made a representation to Makate that Geissler had authority to conclude the agreement on its behalf. ${ }^{59}$

For a company's statement or conduct to constitute a representation of authority for the purposes of estoppel, it must be that of a person or persons (such as a board of directors) who have actual authority to bind the company to the transaction in dispute. The conduct may include appointing an individual to a position ordinarily carrying with it a particular level of authority or permitting the putative agent to engage in a course of dealing on behalf of the company. A representation by the agent alone, without more, is insufficient. ${ }^{60}$

The principal source of authority in Vodacom was its board of directors, but the executive directors were critically involved in the company's dayto-day operations. The most important executive director was KnottCraig, who was the Group CEO of the holding company of Vodacom and the Executive Chairman of the operating company. Knott-Craig was the driving force behind Vodacom. If he approved a project, it would be undertaken. The product could be launched in the marketplace without

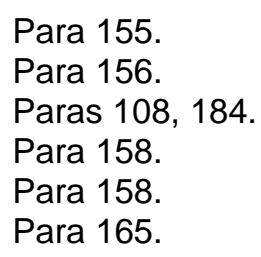


prior board approval, except where it would involve substantial capital expenditure. ${ }^{61}$

Knott-Craig had at least ostensible authority to agree to remunerate Makate for his idea. ${ }^{62} \mathrm{He}$ had used Geissler as his agent, in turn, to engage with Makate. That was entirely compatible with the corporate hierarchy. ${ }^{63}$ Makate did not question Geissler's authority and Geissler did not make any express representations to him about the scope of that authority. This situation was a case of Makate relying on the conduct of senior parties in the company's hierarchy that cloaked Geissler with the appearance of authority to conclude the agreement. ${ }^{64}$

The board of Vodacom had represented to the world, including Makate, that Geissler had the necessary authority to conclude the agreement for remuneration with him. ${ }^{65}$ Knott-Craig had known in substance what was happening between Geissler and Makate and he had done nothing to make it clear to Makate that no agreement on remuneration could be concluded without reference to higher authority in Vodacom. ${ }^{66}$

The consequence was that Geissler had ostensible authority to conclude a contract with Makate and Vodacom was estopped from denying that authority. ${ }^{67}$

\section{Comment}

As is evident from Wallis AJ's minority judgment, the majority decision in this case has significant flaws. Certain additional criticisms should be made.

A major concern is that the decision flouts the principle of stare decisis. This raises the question whether the decision itself is to be regarded as establishing a binding legal precedent. A court is not obliged to follow the decision of a higher court if the decision was arrived at per incuriam, that is, without due regard to the law. ${ }^{68}$ Jafta J's view is an entirely novel one,

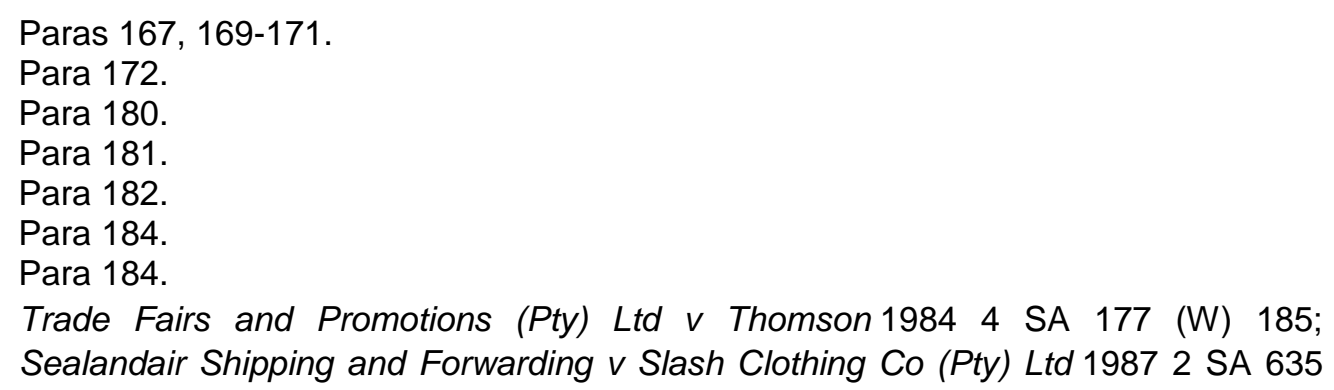


formulated without requiring argument on the point, and founded on an obvious misinterpretation of English law. It conflicts with a voluminous body of South African case law and the view shared by a number of textbook writers. Jafta $\mathrm{J}$ advanced no constitutional imperative and no reason of principle for creating a new rule of law (other than the consideration that the law governing apparent agreement should be analogous to that which applies to dissensus in the law of contract). It is trite that a higher court should not readily depart from a view adopted in a long line of earlier judgments ${ }^{69}$ and it stands to reason that if a higher court does this, it should provide convincing reasons why the earlier view is no longer good law. ${ }^{70}$ In this instance, the earlier view is supported by an extensive body of case law, spanning more than a century, and Jafta $\mathrm{J}$ provided no convincing reason in law or logic for departing from the settled legal position.

A further criticism of the majority judgment (assuming it establishes a binding precedent) is that the principle that it introduces ("the principle") is a rudimentary one that will need to be refined and developed if it is to achieve rational and fair results. Authority is established if a party (the principal), by words or conduct, creates an appearance that another party (the agent) has the power to act on his or her behalf. No other requirement needs to be complied with. The representation of authority need not even be made to the third party who maintains that the agent had power to act. ${ }^{71}$ In the result, authority is created by representation alone: words or conduct which create an impression of authority in the minds of others.

One of the difficulties that arises is that the principle does not distinguish between an intentional and an unintentional representation of authority. The doctrine of estoppel makes this distinction. It provides that where the representation of authority arises from unintentional conduct, the conduct must be "of such a nature that it could reasonably have been expected to

(W) 639-640, 641; Hahlo and Kahn Union 30. Cf Makambi v MEC for Education, Eastern Cape 20085 SA 449 (SCA) para 28.

69 See, eg, De Villiers v McIntyre 1921 AD 425 432; Kergeulen Sealing and Whaling Co Ltd v Commissioner for Inland Revenue 1939 AD 487 505; Phillips $v$ Commissioner For Inland Revenue 1942 AD 35 50; The Mine Workers' Union v JJ Prinsloo; The Mine Workers' Union V JP Prinsloo; The Mine Workers' Union $v$ Greyling 19483 SA 831 (A) 852; Holmes' Executor v Rawbone 19543 SA 703 (A) 711; Hahlo and Kahn Union 30-31.

70 Bosch v Commissioner, South African Revenue Service 20135 SA 130 (WCC) para 103.

$71 \quad$ Para 47. 
mislead". ${ }^{72}$ The reason for making this distinction and applying an objective standard is that a court should not, in fairness, hold a person bound by "consequences which he could not reasonably expect and are not the natural result of his conduct" (Monzali v Smith). ${ }^{73}$ In Connocks (SA) Motors Co Ltd $v$ Sentrale Westelike Ko-Operatiewe Maatskappy Bpk, ${ }^{74}$ Trollip J explained:

It is obvious ... that to have regard only to the position of the representee in applying the objective test could in certain circumstances bear unjustly or unduly harshly on a representor, especially if he was innocent or blameless, and because the foundation of estoppel is still equity, our Courts have evolved a different approach in estoppel based on unintentional conduct in applying an objective test.

Another weakness in the principle is that it does not allow for the possibility that a representation of authority may have no causal effect on the third party. If the principle is applied as formulated by Jafta $\mathrm{J}$, the third party can proceed on the basis that the agent has authority to act, even if the third party has not been misled by the principal's representation of authority or ought reasonably to have known that the agent did not have authority. This is clearly potentially unfair to the principal. A possible solution may be to accept Jafta J's view that authority by representation is analogous to quasi-mutual assent and to apply the requirements of the latter principle in cases of authority by representation. For the doctrine of quasi-mutual assent to apply, the party seeking to uphold a contract without consensus must actually believe that the other party has assented to his or her terms, the belief must be reasonable in the circumstances, and the belief must be engendered by the words or conduct of the other party. ${ }^{75}$ If one applies these requirements, suitably modified, to authority by representation it means that the third party must actually believe that authority has been granted; his or her belief must be caused by the words or conduct (the representation of authority) of the principal; and the belief must be reasonable in the circumstances. Insisting on proof of these elements will ensure that a principal is held liable only if the third party has

72 See, eg, Strachan v Blackbeard \& Son 1910 AD 282 289; Monzali v Smith 1929 AD 382 386; Connocks (SA) Motors Co Ltd v Sentrale Westelike Ko-Operatiewe Maatskappy Bpk 19642 SA 47 (T) 50.

731929 AD 382386.

$74 \quad 19642$ SA 47 (T) 50.

75 See, eg, Steyn v LSA Motors Ltd 19941 SA 49 (A) 61; Sonap Petroleum (SA) (Pty) Ltd (formerly known as Sonarep (SA) (Pty) Ltd v Pappadogianis 19923 SA 234 (A) 241; Hlobo v Multilateral Motor Vehicle Accidents Fund 20012 SA 59 (SCA) para 12; HNR Properties CC v Standard Bank of SA Ltd 20044 SA 471 (SCA) para 23; Constantia Insurance Co Ltd v Compusource (Pty) Ltd 20054 SA 345 (SCA) para 17; Cecil Nurse (Pty) Ltd v Nkola 20082 SA 441 (SCA) para 15. 
genuinely and reasonably relied upon the principal's representation of authority.

It is regrettable that the majority judges in Makate saw fit to introduce a novel and problematic principle into the law governing agency contracts when a satisfactory outcome to the case was easily obtainable through the application of well-established principles. Apart from estoppel, it seems that the principle of "usual authority" could have been invoked to deal with matter. There is substantial case authority to the effect that where a person is employed in a particular position or engaged to carry out a particular task, it is implied that he or she has the actual authority to perform juristic acts that are usually or customarily vested in such an agent. ${ }^{76}$ This authority enables the agent to perform juristic acts which are necessary for, or reasonably incidental to, the due execution of his or her duties or the task assigned to him or her. ${ }^{77}$ In the matter under consideration, it seems obvious that Geissler, given his position in Vodacom, the extensive powers afforded to him in relation to product development, and the organisational structure and internal processes of Vodacom, would at the very least have had implied authority to agree on the remuneration for which a new product would be acquired by Vodacom. Geissler was, as Jafta $\mathrm{J}$ observed, "best placed to determine the worth of a new product". As such he must have had implied authority to make the contract that he concluded with Makate.

\section{Conclusion}

The majority decision in Makate $v$ Vodacom (Pty) Ltd recognises a new form of actual authority - authority by representation. As explained in the minority judgment, the view taken by the majority judges is based on a misinterpretation of English law and is inconsistent with an extensive body of South African case law and the view shared by several text-book writers. It remains to be seen whether the decision will be regarded as

76 See, eg, Strachan v Blackbeard \& Son 1910 AD 282 288; Reed v Sager"s Motors (Pvt) Ltd 19701 SA 521 (RA) 524-525; Inter-Continental Finance and Leasing Corporation (Pty) Ltd $v$ Stands 56 and 57 Industria Ltd 19793 SA 740 (W) 748; Glofinco v Absa Bank Ltd (t/a United Bank) 20012 SA 1048 (W) 1058-1060.

77 See, eg, Natal Bank Ltd v Parsons 1906 TH 102 112; Maytham v Logan 1917 SR 80 84; Nel v South African Railways and Harbours 1924 AD 30 42-43; Heidrich $v$ Henckert 1930 SWA 26 28; Mahomed v Padayachey 19481 SA 772 (A); Covary v Registrar of Deeds 19483 SA 183 (C) 189; Clifford Harris (Rhodesia) Ltd v Todd 19553 SA 302 (SR) 304; Mineworkers" Union v Cooks 19591 SA 709 (W) 713; Broderick Motors Distributors (Pty) Ltd v Beyers 19682 SA 1 (O) 4; National Board (Pretoria) (Pty) Ltd v Swanepoel 19751 SA 904 (W) 911; Tuckers Land and Development Corporation (Pty) Ltd v Perpellief 19782 SA 11 (T) 14. 
binding precedent and, if it is, whether it will have the effect of rendering the doctrine of estoppel redundant in this context. If the majority decision is accepted as binding, the principle of agency by representation which it establishes will need to be clarified and developed to ensure that it performs a useful and equitable role in resolving agency contract disputes.

\section{Bibliography}

De Villiers and Macintosh Agency

De Villiers JE and Macintosh JC The Law of Agency in South Africa 3 ed (Juta Cape Town 1981)

De Wet and Van Wyk Kontraktereg

De Wet JC and Van Wyk AH Die Suid-Afrikaanse Kontraktereg en Handelsreg vol 14 ed (Butterworths Durban 1978)

Du Bois Wille's Principles

Du Bois $F$ (ed) Wille's Principles of South African Law 9 ed (Juta Cape Town 2007)

Hahlo and Kahn Union 30

Hahlo HR and Kahn E The Union of South Africa, The Development of its Laws and Constitution (Juta Cape Town 1960)

Joubert Verteenwoordigingsreg

Joubert DJ Die Suid-Afrikaanse Verteenwoordigingsreg (Juta Cape Town 1979)

Kerr Agency

Kerr AJ The Law of Agency 3 ed (Butterworths Durban 1991)

Sonnekus Estoppel

Sonnekus JC The Law of Estoppel in South Africa 3 ed (LexisNexis Durban 2012)

Wille Mercantile Law

Wille G Wille and Millin's Mercantile Law of South Africa 18 ed (Hortors Johannesburg 1984)

\section{Case law}

African Life Assurance Co Ltd v NBS Bank Ltd 20011 SA 432 (W)

Armagas Ltd v Mundogas SA (The Ocean Frost) [1986] 2 All ER 385 (HL) 
Benjamin v Gurewitz 19731 SA 418 (A)

Broderick Motors Distributors (Pty) Ltd v Beyers 19682 SA 1 (O)

Cecil Nurse (Pty) Ltd v Nkola 20082 SA 441 (SCA)

Central South African Railways v James 1908 TS 221

Clifford Harris (Rhodesia) Ltd v Todd 19553 SA 302 (SR)

Connocks (SA) Motors Co Ltd $v$ Sentrale Westelike Ko-Operatiewe Maatskappy Bpk 19642 SA 47 (T)

Constantia Insurance Co Ltd v Compusource (Pty) Ltd 20054 SA 345 (SCA)

Covary v Registrar of Deeds 19483 SA 183 (C)

De Villiers v Mclntyre 1921 AD 425

Freeman \& Lockyer (a firm) v Buckhorst Park Properties (Mangal) [1964] 1 All ER 630 (CA)

Holmes' Executor v Rawbone 19543 SA 703 (A)

Glofinco v Absa Bank 20026 SA 470 (SCA)

Glofinco v ABSA Bank Ltd (t/a United Bank) 20012 SA 1048 (W)

Heidrich v Henckert 1930 SWA 26

Hely-Hutchinson v Brayhead Ltd [1968] 1 QB 549 (CA) 583

Hlobo v Multilateral Motor Vehicle Accidents Fund 20012 SA 59 (SCA)

HNR Properties CC v Standard Bank of SA Ltd 20044 SA 471 (SCA)

In Re Reynolds Vehicle and Harness Factory Limited (1906) 23 SC 703

Insurance Trust \& Investments v Mudaliar 1943 NPD 45

Inter-Continental Finance and Leasing Corporation (Pty) Ltd v Stands 56 and 57 Industria Ltd 19793 SA 740 (W)

Kergeulen Sealing and Whaling Co Ltd $v$ Commissioner for Inland Revenue 1939 AD 487 
Lucey \& Co Ltd v Martial \& Son 1931 NPD 47

Mahomed v Padayachey 19481 SA 772 (A)

Makambi v MEC for Education, Eastern Cape 20085 SA 449 (SCA)

Maytham v Logan 1917 SR 80

Mineworkers' Union v Cooks 19591 SA 709 (W)

Monzali v Smith 1929 AD 382

Natal Bank Ltd v Parsons 1906 TH 102

National Board (Pretoria) (Pty) Ltd v Swanepoel 19751 SA 904 (W)

NBS Bank Ltd v Cape Produce Company Pty Ltd 20021 SA 396 (SCA)

Nel v South African Railways and Harbours 1924 AD 30

Northern Metropolitan Local Council v Company Unique Finance (Pty) Ltd 20125 SA 323 (SCA)

Peddie and Drummond v Heydorn 1913 OPD 102

Peri-Urban Areas Health Board v Breet 19583 SA 783 (T)

Phillips v Commissioner for Inland Revenue 1942 AD 35

Reed v Sager's Motors (Pvt) Ltd 19701 SA 521 (RA)

Saambou-Nasionale Bouvereniging v Friedman 19793 SA 978 (A)

Sonap Petroleum (SA) (Pty) Ltd (formerly known as Sonarep (SA) (Pty) Ltd v Pappadogianis 19923 SA 234 (A) 241

Sealandair Shipping and Forwarding v Slash Clothing Co (Pty) Ltd 19872 SA 635 (W)

South African Broadcasting Corporation v Coop 20062 SA 217 (SCA)

Southern Life Association Ltd v Beyleveld 19891 SA 496 (A)

Steyn v LSA Motors Ltd 19941 SA 49 (A) 61

Strachan v Blackbeard \& Son 1910 AD 282 
The Mine Workers' Union v JJ Prinsloo; The Mine Workers' Union v JP Prinsloo; The Mine Workers' Union v Greyling 19483 SA 831 (A)

Trade Fairs and Promotions (Pty) Ltd v Thomson 19844 SA 177 (W)

Tuckers Land and Development Corporation (Pty) Ltd v Perpellief 19782 SA $11(\mathrm{~T})$

Van Blommenstein v Holliday (1904) 21 SC 11

Van Ryn Wine and Spirit Co v Chandos Bar 1928 TPD 417

Welgedacht Exploration Co Ltd v Transvaal and Delegoa Bay Investment Co Ltd 1909 TH 90

West v De Villiers 1938 CPD 96103

West v Pollak \& Freemantle 1937 TPD 64 